\title{
Origin of sediment column profiles of gases and organic matter at a Laptev Sea gas seeps area (Arctic)
}

\author{
VYACHESLAV SEVASTYANOV ${ }^{1}$, VALERIA \\ FEDULOVA $^{2}$, VENIAMIN FEDULOV ${ }^{2}$, OLGA \\ KUZNETSOVA $^{2}$, NIKITA DUSHENKO ${ }^{2}$ AND ALENA \\ VINNIKOVA $^{2}$ \\ ${ }^{1}$ Vernadsky Institute of Geochemistry and Analytical Chemistry \\ of Russian Academy of Sciences \\ ${ }^{2}$ Vernadsky Institute of Geochemistry and Analytical Chemistry \\ Presenting Author: vsev@geokhi.ru
}

Gas seeps provides indirect information on deeper subsurface deposit of hydrocarbons that can potentially aid exploration.Two closely spaced seep areas in the Laptev Sea have been studied: Oden (station 5953-3) and C15 (station 5947). The areas of methane seeps are located close to the junction of the Gakkel Ridge with the fault system on the shelf. Station 5953-3 was located in the immediate vicinity of the bubble gases release from the marine sediment. Samples of the sediments were collected using a box corer. To assess diagenetic OM transformation in marine sediments fraction-specific carbon isotope distributions (FCID) have been analyzed. FCID represents a valuable tool to characterize the diagenesis because the shape of isotope type-curve depends on the OM transformation. $\mathrm{OM}$ was separated into five fractions: the nonpolar hexane fraction $(\mathrm{H})$, three fractions of increasing polarity hexane-benzene (HB), benzene (B) and benzenemethanol (BM), and asphaltenes (A). The $\delta^{13} \mathrm{C}$ values of the fraction varied in a wide range from -40 to $-28 \%$. The $\delta^{13} \mathrm{C}$ values of BM fractions were very low. This is due to the deep oxidation of $\mathrm{BM}$ resin. The following hydrocarbon gases were measured: $\left(\mathrm{CH}_{4}, \mathrm{C}_{2} \mathrm{H}_{4}, \mathrm{C}_{2} \mathrm{H}_{6}, \mathrm{C}_{3} \mathrm{H}_{6}, \mathrm{C}_{3} \mathrm{H}_{8}, \mathrm{C}_{4} \mathrm{H}_{8}, \mathrm{n}-\mathrm{C}_{4} \mathrm{H}_{10}\right.$, i$\mathrm{C}_{4} \mathrm{H}_{10}, \mathrm{n}-\mathrm{C}_{5} \mathrm{H}_{12}, \mathrm{i}-\mathrm{C}_{5} \mathrm{H}_{12}, \mathrm{n}-\mathrm{C}_{6} \mathrm{H}_{14}$, neo- $\left.\mathrm{C}_{5} \mathrm{H}_{12}\right), \mathrm{CO}_{2}, \mathrm{CH}_{3} \mathrm{SCH}_{3}$, COS. Neopentane origin is directly related to the thermal maturation of oil. A characteristic feature of the composition of gases from the column of station 5953-3 represents a significantly increased concentration of hydrocarbons. Thus, the average methane concentration was $16.5 \mathrm{mg} \mathrm{L}^{-1}$ at station 5953-3 and $5.3 \mu \mathrm{g} \mathrm{L}^{-1}$ at station 5947. The thermogenic nature of the emitted gases is indicated by a significant excess of the concentration of saturated hydrocarbons (HC) compared with the concentration of unsaturated $\mathrm{HC}$ by 1-2 orders of magnitude. The $\delta^{13} \mathrm{C}$ values of $\mathrm{CH}_{4}$ in the vertical profile of core 5953-3 varied from $-80 \%$ on the surface to $-58 \%$ at a depth of $22 \mathrm{~cm}$. The $\delta^{13} \mathrm{C}$ values of $\mathrm{CO}_{2}$ reached $-15.9 \%$ on the surface. The movement of gas to the surface causes active microbiological processes in the thickness of the sediment and on its surface. 